\title{
Lateral
}

Journal of the Cultural Studies Association

\section{Introduction: Cultural Constructions of Race and Racism in the Middle East and North Africa / Southwest Asia and North Africa}

by Rayya El Zein I Cultural Constructions of Race and Racism in the Middle East and North Africa / Southwest Asia and North Africa (MENA/SWANA), Issue 10.1 (Spring 2021)

\begin{abstract}
In recent years, scholars in the fields of cultural studies, American studies, history, ethnic studies, and Middle East area studies have approached questions of race and racism in this geographic region with renewed critical vigor. Recent work deconstructing anti-Arab racism and Islamophobia in the Americas and Europe has put these patterns of discrimination into intersectional conversation with anti-Black and anti-Indigenous racism. New historical efforts have drawn attention to the legacies of slavery in the Ottoman, Persian, and Arab Empires, working to understand how forms of racialization and racial hierarchization predated and were exacerbated by the arrival of European imperial forces. At the same time, activists in the region draw attention to prevailing racism against migrant laborers, marginalized indigenous populations, and others as the afterlives of colonialism, war, austerity, and revolution carry on. Together, this academic and activist work asks for attention by leaders, community members, and scholars of this region to the particularities of racecraft in the region: How are "Blackness" and "whiteness" constructed in the Arabic, Hebrew, Persian, and Turkish speaking worlds? What are the obstacles to discussing and identifying race particular to the histories of this region, its peoples, and its histories? This forum uses close readings of popular culture and political discourse across the Middle East and North Africa / Southwest Asia and North Africa (MENA/SWANA) in pursuit of these questions and others.
\end{abstract}

KEYWORDS anti-Blackness, area studies, cultural studies, MENA, Middle East, North Africa, race, racialization, racism, Southwest Asia, SWANA

I come to this forum as someone learning about race and racialization in places I call home. Specifically, I come to the job of soliciting and editing the pieces in this forum Cultural Constructions of Race and Racism in the Middle East and North Africa / Southwest Asia and North Africa (MENA/SWANA) 1 as part of a process of interrogating white supremacy and anti-Black racism between the United States and the Arab Levant.? Some of the authors of forum entries have been researching and writing about race in the region for some time; some are newer to these conversations. Most of us speak the languages relevant to our research contexts and/or have spent significant time in residence there. Many of us identify as POC, but most do not identify as Black. I begin with this foregrounding of authorial subject positions because, as historian and Africana scholar Eve Troutt Powell put it recently, "nobody comes to these discussions cold." 3 - That is, for all of us writing, and likely for many reading, personal experiences brought us to these questions and intimate attachments keep us asking them.

The pieces collected in this forum were written and edited during a period when the shape and impact of anti-Black racism in the MENA/SWANA and its diasporas appeared to regain poignancy in the wake of current events. -4 The murder of George Floyd by Minneapolis 
police officers in May of 2020 cast a spotlight on the role of Arab clerks and corner store owners as unfortunate intermediaries between Black communities and police departments in the United States. This attention summoned a renewed, if brief, investigation of antiBlack racism within Arab-American and other hyphenated communities from the MENA/SWANA. .5 Meanwhile, in the Arab world, in Lebanon for example, waves of protest for structural change have belatedly also included calls to address patterns and structures of racism. Protests against the deplorable kafala, or sponsorship system, have been growing in recent years, including during the so-called October Revolution (2019) against corruption and the sectarian regime. 6 The global pandemic continues to reveal the cruelty of that system in which employers wield incredible power over the lives of migrant workers - many of them female domestic workers residing in the homes of their employers and at the whim of their discretion about any number of considerations from what and how much they eat, to access to travel documents, to pay.

However, many MENA/SWANA contexts have also seen the appropriation of the "Black Lives Matter" slogan during protests staged for an international audience that do not center the rights or concerns of Black community members. Turkish students fearing contagion during the COVID-19 pandemic used the hashtag \#TurkishStudentLivesMatter to petition against procedures for end of year exams. Iranian activists have used the slogan \#IranianLivesMatter to draw attention to a number of individual cases of police brutality and capital punishment in addition to the US-led blockade of the country. In Lebanon and Palestine, pushback against the use of "Lebanese Lives Matter"? and "Palestinian Lives Matter"- 8 slogans-and the continued demand to recognize the existence of Afro-Arabsasks Arab activists who are white-passing to deepen the anti-racist work in their organizing. Celebrations of and enthusiasm about music, fashion, and other cultural production read as "Black" attempts to focus emphasis away from anti-Black racism, colorism, and white supremacy as it exists in all of these contexts. $\frac{9}{-}$ The appropriations of the Black Lives Matter slogan must be read together with histories of radical, intersectional struggle and alongside other appropriations of Black culture and affect in the region.

Over the past decade, thinkers and activists of different subject positions have sought to excavate and reconstruct histories and practices of solidarity between (largely) US Black communities and activists and different politicized communities in the MENA. 10 Most prominent here has of course been the question of solidarity between (again largely) African-Americans under a Jim Crow and Jim Crow-descended US prison system and Palestinians under Israeli Occupation. I have followed this work with great personal and political interest but I confess to finding the conclusions sometimes out of joint.

Examinations of the intersections of the Israeli and US carceral states or military industrial projects and comparative analyses of settler colonial states are surely helping to grow international awareness of the situation in Palestine. But are they helping Palestinians undo white supremacy in our own communities? Does the excitement about interracial solidarity reveal a hesitancy to ask difficult questions about race-based discrimination? How can these be reconciled?

This forum is imagined as a tool to deepen the ongoing work of recognizing, naming, and undoing white supremacy, colorism, and anti-Black racism in the MENA/SWANA. The entries take up the call by Afro-Iranians, Afro-Arabs, Afro-Turks to identify and root out everyday racism and colorism perceived to be harmless. 11 The forum begins from the recognition that many non-Black MENA/SWANA communities, grappling as they are with the historical legacies of European colonial violence and neo-imperialism in the shape of the global war on terror, have struggled to also recognize the local and regional lineages of 
empire and colonialism that continue to dispossess and discriminate racially in this region. Forum entries draw their strength from intimate familiarity with and connections to these communities and began with the premise that before staking claims to solidarity, more work needs to be done by the non-Black members of our communities to rise to the call of our Black neighbors, classmates, colleagues, family members to identify, recognize, and undo practices of racialization, colorism, and other race-based discrimination.

For example, several of the pieces in this forum refer to or critically examine blackface performances (Baghoolizadeh, Vaziri, Willoughby). In richly mediated entries on Iranian theatre, film, comics, and Turkish television commercials, the authors gesture towards the intermedial (between for example film and comics) and intercultural ways (between for example Turkey and the US) in which these practices cohere. That is, besides discussing various aspects of these nefarious representations, the entries in this forum also attempt to explore how they work. This deepens a discussion of race and racism beyond a critical identification and reproach of racist ephemera and into the realm of cultural racecraftwhat these representations do and how they resonate, elide, and endure.

In addition, several of the pieces in this forum are in direct conversation with or propose their own radical treatments of inter-ethnic and interracial discourse, allyship, and critique (Burris, Crasnow, Davis, Nickell and Benkato, Sprengel and Silverstein). The frameworks they excavate however, rarely champion a formed, determined solidarity. Rather, these authors critique what they see as normative frameworks of solidarity, multicultural discourse, tolerance, and transnational "wokeness" in order to tease out how the 
production of liberalism as development, as multiculturalism, as feminism, and as leftism can work hand in hand with modulations of white supremacy.

This forum asks what particular textures cohere around whiteness, indigeneity, Arabness, Iranianness, Israeliness, Turkishness, and anti-Black racism in the MENA/SWANA? What are the economic and geopolitical histories and cultural and media lineages that inflect this racism? What histories of slavery and empire specific to the region must be rendered familiar in order to recognize and unravel textures of anti-Black racism in Arabic, Turkish, Persian, and Hebrew-speaking contexts? Finally, how can this analysis, drawn from intimate knowledge of the history of the SWANA, its languages, cultural production, and accompanying structures of feeling be used to deepen and complexify a global struggle against white supremacy and anti-Black discrimination, dispossession, and oppression?

\section{Approaching Race and Racism in the MENA/SWANA}

For decades, a common retort within MENA/SWANA studies and among MENA/SWANA communities has been that racism as it is understood in the US context is not applicable in this region. This argument goes that the realities of the transatlantic slave trade, the lineages of racism descended from it, and thus the theoretical and political frameworks developed around race in the US are not applicable to the MENA/SWANA region, where the transatlantic slave trade did not reach. These defensive protestations frequently point to the brutality of American plantation slavery in a distancing mechanism that qualifies as lesser any discrimination darker-skinned individuals may face in the MENA/SWANA. Yet, Black communities in the region and Black scholars working on race-based discrimination, histories of slavery, and contemporary legal and labor codes have protested the silencing and erasures enacted by these defensive postures from non-Black speakers. Important as it is to provincialize US empire, and with it, patterns of racialization born of that context, accusations of US-centrism-since they frequently silence an often Black speaker-have largely suppressed anti-racist critiques in MENA/SWANA contexts. That is, accusations of US-centrism have largely not encouraged the proliferation of other work on race, slavery, colorism, and empire that would facilitate a non-US-centric conversation about and struggle against anti-Black racism in MENA/SWANA contexts. Thanks to the efforts of Black activists and scholars, this does appear to be changing, albeit slowly. Recent months have seen some public efforts in MENA/SWANA academic communities of addressing these erasures. $\frac{12}{2}$

At the same time, the terrifying global advance of the so-called war on terror since 2001 has proliferated racializations of Arab and Muslim bodies. These have produced a matrix of representations of the racially abject that are at a remove from racialized Blackness while not disconnected from it (see Davis and Crasnow in this forum). 13 More complicated, brown and Muslim bodies rendered abject by US empire have found themselves at the violent whims of a "post"-racial multicultural liberalism (see Sprengel and Silverstein in this forum). While the most spectacular example finds itself in the drone warfare of former US president Barack Obama, college campuses across the country have found themselves bifurcated by race and class around the question of US military involvement in the MENA/SWANA. In 2013, when ROTC recruiting was then being reconsidered for reinstatement at Medgar Evers College in Brooklyn after a forty-year hiatus, I saw in my 
own classrooms how the tools available for discussing racism in these communities frequently falls short.14 During the town hall on the question of whether the ROTC should resume recruiting at the college serving the rapidly gentrifying neighborhood of Crown Heights, the racial animus grew audibly between working-class Black students, promised opportunity and tuition-free education through the ROTC program, and first- and secondgeneration Iraqi and Afghani students, who acutely felt the threat to people and places close to home manifest through that expansion of the military industrial complex. This animus cannot be explained by gestures towards an ancient and essentialized antiBlackness, somehow intrinsic to the region, to its politics, or to Islam. $\frac{15}{\text { Similarly, pointing }}$ solely to the reality of US imperial intervention masks other histories and power struggles that, while they cannot trump US power or other Western intervention, are no less nefariously implicated by the racialized hierarchies of white supremacy, even when they are manifest in communities of color.

Some iteration of these points and dynamics can be recognized in almost any discussion of race and racism in the MENA/SWANA. Is there a way around these affective and discursive pillars-neither defeatist nor triumphant-towards new conversations about race-making and racialization in the MENA/SWANA? One goal of the forum is to do just this. The forum collects short pieces that focus in on one aspect of racecraft as it is manifested across a mini-archive of cultural ephemera. These analyses testify to some of the myriad practices of race-making in everyday life. Read together, they offer different entry points to conversations of race and racecraft in the MENA/SWANA.

\section{Cultural Constructions of Race and Racism in the MENA/SWANA}

The scope of this forum is bracketed in specific ways. By focusing on cultural constructions of race and racism, the forum draws attention to the way race-making works in popular culture. Analyses of film, theatre, dance, music-making, and comics draw out some of the images, sounds, and aesthetics of racemaking in specific contexts. At the same time, the nine authors of the forum also analyze how practices of racialization signaled by these cultural forms cohere in regional and transnational flows of power and legibility. The forum elaborates a wide-ranging and occasionally unwieldy conversation about the particularities of race-making in historical and geographical contexts that are not tethered to the transatlantic slave trade and its legacies. In the place of those worldripping lineages, authors point to local and regional referents that construct and have constructed racecraft and racism in this region.

As such, the forum makes a modest but specific contribution to an already substantial body of scholarly and activist work on Blackness, whiteness, and indigeneity in the MENA/SWANA (see Tayeb < https://csalateral.org/forum/cultural-constructions-raceracism-middle-east-north-africa-southwest-asia-mena-swana/whiteness-in-north-africatayeb/> in this forum). In closely reading pieces of visual and sound media and events, the forum collects an archive of material through which to recognize and dissect contemporary workings of racecraft in the region. This collection of discomfiting and upsetting material demands to be reckoned with—not as remnants of a foregone era, nor as imports from the US or the "West"—but as evidence of contemporary, homegrown patterns of racialized associations, dispossessions, and disappearances. At the same time, 
neither is the forum a haphazard collection of racist ephemera. Across the forum, close readings of popular culture draw out, to borrow from Jemima Pierre, "the construction, constitution, and maintenance of racial categories and meanings-the processes of racialization." 16 Entries lean on selected media to illustrate selected practices of racemaking.

These entries draw on certain lineages of scholarly research. The forum's closing entry, "What Is Whiteness in North Africa?" sketches these out as an expanded invitation to further reading. A few of these threads are mentioned here in order to help ground and position the forum interdisciplinarity between cultural studies and MENA/SWANA area studies. Major advances by MENA historians Eve Troutt Powell, Chouki El-Hamel, Ehud Toledano, Mathew S. Hopper, and Sussan Babaie, among others have made specific the particular contours of slavery specific to the region. 17 These works have foregrounded that understanding anti-Black racism in the region requires attention to the histories of slavery, indebtedness, confinement, and the overlapping colonial geographies lived in the MENA/SWANA. 18 Many of the forum's entries reference this literature. Indeed, that they do so gestures to how a cultural studies of the MENA/SWANA might benefit from similarly foregrounding these works. Besides this historical work, key studies of cultural production by Cynthia Becker, Richard C. Jankowsky, Ella Shohat, Ammiel Alcalay, Ida Meftahi, and Pedram Partovi from the disciplines of art, anthropology, literature, ethnomusicology, dance, and film have connected historical and contemporary contexts in important ways. $\underline{19}$ Authors in this forum additionally draw on regional analyses of nationalism; $\underline{20}$

anthropological treatments of identity; ${ }_{i} 1$ and work addressing the racialization of Jews and Muslims in the US and Europe. $\frac{22}{}$ All of these further flesh out a corpus of cultural studies of the MENA/SWANA critically attuned to questions of racecraft.

Important for the elaboration of the cross section between cultural studies and MENA/SWANA studies that I attempt here, authors are not limited citationally to scholarship on the region. They draw from literature that analyzes race and meaning making in other contexts as well. As gestured to above, entries in the forum draw on anthropological studies of racialization, especially that of racecraft as proffered by Jemima Pierre in her work on postcolonial Ghana. In addition, authors draw on analyses of race and music drawing from hip hop studies, performance studies, and sound studies. $\frac{23}{}$ Multiple entries draw on studies of blackface both in the US and outside of it and several refer to racial dynamics in literature, film, dance, comics. $\underline{24}$ Others draw on studies of neoliberal subjectivity and neoliberal security states. $\frac{25}{}$

This intersection of literature supports forum authors as they follow their material archives and the "invitation[s they offer] to escape national and colonial epistemologies." 26 The framework of "cultural constructions of race and racism" is deliberately chosen to mirror contemporary emphasis in cultural studies writ large away from race as an identity or as difference. 27 The forum is less committed to building an understanding of different racialized identities in the region (Black, indigenous, white, et al.) or racialized essences (Blackness, whiteness, etc.) and the distances between them, as it is to calling attention to how racialized meaning coheres, is produced, is sustained. In this, the forum most directly leans on cultural studies' legacy of audiences and reception, while it feels out what practices of racialization rooted in the MENA/SWANA might contribute to analysis of coloniality/decoloniality and other postcolonial models of power.

Other threads of critical debates in the study of race and anti-racist struggle also appear. The debate over intersectionality, while not addressed in entries explicitly, resonates in 
attention to overlapping colonial vestiges and how local, regional, and transnational power multiply interpellate MENA/SWANA subjects. Indeed, while the debate over and recognition of "matrixes of domination" in the US context have foregrounded recognition of how race, class, and gender simultaneously work on different subjects, forum authors here ask for recognition of how nation, empire, ethnicity, sect, religion-in addition to class, gender, and race-also intersect and interpellate subjects in the region and its diasporas. 28 Finally, forum entries also operate with an awareness of the recent deepening of the debate over Afropessimism and the influence of a notion of an anti-Black ontology on the study of race in this region and outside of it. Muriam Davis's entry, "Incommensurate Ontologies?: Anti-Black Racism and the Question of Islam in French Algeria" is most explicit in this engagement, while the forum as a whole gestures towards the need for further elaboration of what shape "social death" 29 as a result of specific patterns of immigration, dispossession, representation, repression in this region takes, and, as a result, to what extent recent accusations of regional anti-Blackness should hold. .30

We begin with Beeta Baghoolizadeh's exploration of the Iranian figure Haji Firuz < https://csalateral.org/forum/cultural-constructions-race-racism-middle-east-north-africasouthwest-asia-mena-swana/myths-haji-firuz-racist-contours-iranian-minstrelbaghoolizadeh/> . Popular during the Persian New Year festival, Nowruz, Baghoolizadeh explores how this popular blackface character has been defended as "tradition" while experiencing periods of official disavowal by the Islamic Republic. Baghoolizadeh shifts her inquiry from who is Haji Firuz and where did he come from? to who is Haji Firuz and how do we let him go? -pointing to the work she identifies as necessary for contemporary Iranians to face and accept histories of slavery and Afro-Iranian erasure. Her analysis is echoed by Parisa Vaziri in a later entry in the forum, which traces how the character moves across other media like film and comics.

From here, the forum hosts two jointly-authored pieces, putting examples from Egypt and Syria and from Libya and Lebanon, respectively, in direct conversation with each other. Both pieces explore constructions of race in music and music industries. The first, "An (Un)Marked Foreigner: Race-Making in Egyptian, Syrian, and German Popular Cultures" < https://csalateral.org/forum/cultural-constructions-race-racism-middle-east-north-africasouthwest-asia-mena-swana/unmarked-foreigner-race-egyptian-syrian-german-popularcultures-silverstein-sprengel/> by Shayna Silverstein and Darci Sprengel begins with the ethnographers' recognition of persistent refusal to engage the 'concept of race' among their Arab interlocutors. Exploring logics of security and tolerance as they appear in the touring and immigration patterns of their research partners, Sprengel and Silverstein argue for the recognition of "global configurations of identity, culture, and empire" including but not limited to celebrations of multiculturalism widespread in the US and Western Europe. Their entry gestures towards how cultures of multiculturalism and security are reflected and refracted from Europe (Italy, Germany) to the Arab world (Egypt, Syria). In the second coauthored piece, "On Blackness and the Nation in Arab Hip Hop," < https://csalateral.org/forum/cultural-constructions-race-racism-middle-east-north-africasouthwest-asia-mena-swana/blackness-nation-arabic-hip-hop-lebanon-libya-nickellbenkato/> Chris Nickell and Adam Benkato examine flare-ups of anti-Blackness within the genre of hip hop in Arabic. Nickell takes as his example one of the early iterations of rap "battles" staged in Beirut, Lebanon in 2015, where Lebanese emcees confront each other in overtly racist jibes, while Benkato explores how constructed characters in Libyan music video clips reinforce specific ideas about blackness, Libyanness, and violence in the years following Qaddafi's ouster. Their piece asks hip hop makers and fans (and hip hop studies) 
to consider critically the circulation of racialized stereotypes while it presses for an articulation of hip hop masculinity so far left unelaborated by a slate of scholarship celebrating hip hop and the so-called "Arab Spring."

Bam Willoughby's entry, "Opposing a Spectacle of Blackness: Arap Baci, Baci Kalfa, Dadi, and the Invention of African Presence in Turkey" < https://csalateral.org/forum/culturalconstructions-race-racism-middle-east-north-africa-southwest-asia-menaswana/opposing-spectacle-blackness-arap-baci-kalfa-dad-african-presence-turkeywilloughby/> explores twin features of visual representation for an Afro-Turk community. Highlighting commercial circulations of Black women in the characters of Arap Kizi and Baci Kalfa in ads for sweets and soap, Willoughby analyzes how the drag performance builds specific ideas about domesticity in the Turkish cultural landscape. Sascha Crasnow then elaborates the first of two pieces about ethnic erasure in contemporary Israel. Crasnow explores the appropriation and de-Arabization of Yemeni dance in Israeli culture $<$ https://csalateral.org/forum/cultural-constructions-race-racism-middle-east-northafrica-southwest-asia-mena-swana/cooption-erasure-mizrahi-culture-israel-crasnow/> through a close examination of the work of Leor Grady. Her piece offers an exploration of white supremacy in Ashkenazi and Mizrahi communities in Israel. From here, Muriam Davis reads anti-Black racism and Islamophobia together in an unpacking of the rhetoric of the French Left < https://csalateral.org/forum/cultural-constructions-race-racism-middleeast-north-africa-southwest-asia-mena-swana/incommensurate-ontologies-anti-blackracism-islam-french-algeria-davis/> . Elaborating how the colonial occupation of Algeria collapsed distinctions between race and religion, Davis argues for a reading of anti-Black racism and Islamophobia together. From here, Parisa Vaziri returns us to a discussion of the Iranian blackface character Haji Firuz < https://csalateral.org/forum/culturalconstructions-race-racism-middle-east-north-africa-southwest-asia-menaswana/thaumaturgic-cartoon-blackface-vaziri/> to which we began. Contextualizing the figure vis-à-vis other forms of popular culture-1960s comic strips and popular Iranian films (filmfarsi), Vaziri argues for an intermedial understanding of the racial textures of the Nowruz jester.

The two closing pieces draw the forum to a close with critical reflections on whitenessGreg Burris in Israel and Leila Tayeb in North Africa. Burris acknowledges an outpouring of liberal political energy in Israel surrounding the plight of African asylum seekers in the 2010s. However, by considering the representations of these refugees in several documentary Israeli films, he offers an indictment of Israeli liberalism < https://csalateral.org/forum/cultural-constructions-race-racism-middle-east-north-africasouthwest-asia-mena-swana/black-skin-white-cameras-african-asylum-seekers-israelidocumentary-film-burris/> that celebrates white feminism at the continued erasure of African representation. Tayeb's entry emphasizes the "array of things that formations of whiteness do and enable in the context of North Africa." She concludes the forum by outlining suggestions for further reading < https://csalateral.org/forum/culturalconstructions-race-racism-middle-east-north-africa-southwest-asia-menaswana/whiteness-in-north-africa-tayeb/> arguing, "It is imperative that we do not stop at noting the anti-Black racism that we rightly see in these, but rather go on additionally to theorize the racial and spatial whiteness that these practices enable and uphold."

Aware of the multiple audiences which it faces, the forum is imagined as part of ongoing and urgently needed anti-racist work in this region and beyond. 


\section{Notes}

1. While the acronym MENA-Middle East and North Africa-reflects the dominant way in which this region is referred to in academic discussions and media debates, recent activist energy has turned to encourage the use of a less colonized alternative, SWANA-Southwest Asia and North Africa. The latter decenters the Americas and Europe as cartographic center of the planet. Mobilization around the term increased in the late 2010s as activists vied for a MENA/SWANA category on the US census. Americans from this region are currently legally classified as "white"; activists were working towards a new category. The request was denied for the 2020 census. On the use of SWANA over MENA, see a number of university club statements-for example, Center for Culture, Equity, and Empowerment, George Mason University (https://ccee.gmu.edu/swana < https://ccee.gmu.edu/swana/> ). The forum introduction uses MENA/SWANA as a commitment to the new acronym SWANA while recognizing it is less readily recognizable than MENA. On the census, see Sarah Parvini and Ellis Simani, "Are Arabs and Iranians White? Census Says Yes, but Many Disagree," Los Angeles Times, March 28, 2019, https://www.latimes.com/projects/la-mecensus-middle-east-north-africa-race/ < https://www.latimes.com/projects/la-me-censusmiddle-east-north-africa-race/> ; Moustafa Bayoumi, "I'm A Brown Arab-American and the US Census Refuses to Recognize Me," The Guardian, February 14, 2019, https://www.theguardian.com/commentisfree/2019/feb/14/arab-american-census-americaracism < https://www.theguardian.com/commentisfree/2019/feb/14/arab-american-censusamerica-racism>.

2. Specifically, the suburban US Midwest and the urban US Northeast, and Lebanon and Palestine. P

3. Eve Troutt Powell, "Blackness in the Middle East: A Virtual Panel Discussion," September 16, 2020, Middle East Center, University of Pennsylvania, https://drive.google.com/file/d/1t2VI0yoOTRrXWbJpaW-KYeRAwtMtap4b/view < https://drive.google.com/file/d/1t2VI0yoOTRrXWbJpaW-KYeRAwtMtap4b/view> , accessed November 23, 2020.

4. See, for example, Bahira Amin, "Anti-Blackness in the Arab World and the Violence that Doesn't Get a Hashtag," Scene Arabia, June 10, 2020, https://scenearabia.com/Life/Arab-Anti-BlacknessRacism-and-the-Violence-that-Doesn-t-Get-A-Hashtag?M=True <

https://scenearabia.com/Life/Arab-Anti-Blackness-Racism-and-the-Violence-that-Doesn-t-GetA-Hashtag?M=True > ; Joseph Fahim, "Racism in the Middle East: The Arab Films and TV that Promote Hatred," Middle East Eye, June 25, 2020, https://www.middleeasteye.net/discover/racism-middle-east-arab-film-tv-opinion < https://www.middleeasteye.net/discover/racism-middle-east-arab-film-tv-opinion>; "Essential Resources on Racism and Anti-Blackness in the Middle East and North Africa," https://www.pinkjinn.com/2020/06/24/essential-resources-on-racism-and-anti-blackness-inthe-middle-east-and-north-africa < https://www.pinkjinn.com/2020/06/24/essential-resourceson-racism-and-anti-blackness-in-the-middle-east-and-north-africa/ $/<$

https://www.pinkjinn.com/2020/06/24/essential-resources-on-racism-and-anti-blackness-inthe-middle-east-and-north-africa/? fbclid=IwAR1LEoLd8xUKrWVfKKJaN9SCNNA7DLAugY9JGQBj4oB_GjCpn6JHmyzkI7o> .

5. See for example: Moustafa Bayoumi, "Why Did Cup Foods Call the Cops on George Floyd?" The New York Times, June 17, 2020, https://www.nytimes.com/2020/06/17/opinion/george-floydarab-muslims-racism.html < https://www.nytimes.com/2020/06/17/opinion/george-floyd-arabmuslims-racism.html> ; Ahmed Tharwat, "The Holy Land Deli Debacle: Immigration Meets Complication," Star Tribune, June 12, 2020, https://m.startribune.com/the-holy-land-delidebacle-immigration-meets-complication/571226372/ < https://m.startribune.com/the-holyland-deli-debacle-immigration-meets-complication/571226372/> ; "An Un-Holy Land? An Arab Muslim Reckoning with Racism," Code Switch, NPR, July 21, 2020, https://www.npr.org/2020/07/20/892974522/un-holyland-an-arab-muslim-reckoning-withracism < https://www.npr.org/2020/07/20/892974522/un-holyland-an-arab-muslim-reckoningwith-racism> ; AJAM Media Collective, "Iranians for Black Lives: A Guide for Dismantling AntiBlackness in the Iranian-American Community," Facebook, June 2, 2020, https://www.facebook.com/AjamMediaCollective/posts/2931373860265561 < https://www.facebook.com/AjamMediaCollective/posts/2931373860265561>. 
6. Kareem Chehayeb, "'Our Lives Matter': Lebanon's Migrant Workers Fight for Their Rights," Middle East Eye, May 28, 2019, https://www.middleeasteye.net/news/workers-not-slaveslebanons-migrant-workers-take-matters-their-own-hands-0 < https://www.middleeasteye.net/news/workers-not-slaves-lebanons-migrant-workers-takematters-their-own-hands-0> . ?

7. Zeina Karam, "Clashes, Tear Gas in Beirut as Protests Turn to Riots," $A B C$ News, June 6, 2020, https://abcnews.go.com/International/wireStory/lebanese-demonstrators-gather-reboot-massprotests-71106982 < https://abcnews.go.com/International/wireStory/lebanese-demonstratorsgather-reboot-mass-protests-71106982>.

8. Oliver Holmes, "'Palestinian Lives Matter': Israeli Police Killing of Autistic Man Draws US Comparison," The Guardian, June 1, 2020,

https://www.theguardian.com/world/2020/jun/01/palestinian-lives-matter-israeli-police-killingof-autistic-man-draws-us-comparison < https://www.theguardian.com/world/2020/jun/01/palestinian-lives-matter-israeli-police-killingof-autistic-man-draws-us-comparison>. ?

9. Ben Cost, "Instagram Influencers Spark Outrage for Donning Blackface in Support of BLM," New York Post, June 11, 2020, https://nypost.com/2020/06/11/influencers-spark-outrage-fordonning-blackface-in-support-of-blm < https://nypost.com/2020/06/11/influencers-sparkoutrage-for-donning-blackface-in-support-of-blm/>, accessed November 23, 2020.

10. Angela Davis, Freedom Is a Constant Struggle: Ferguson, Palestine and the Foundations of a Movement (New York: Haymarket Books, 2016); Keith P. Feldman, A Shadow over Palestine: The Imperial Life of Race in America (Minneapolis: University of Minnesota Press, 2017); Alex Lubin, Geographies of Liberation: The Making of an Afro-Arab Political Imaginary (Durham: University of North Carolina Press, 2014); Noura Erakat and Marc Lamont Hill, "Black-Palestinian Transnational Solidarity: Renewals, Returns, and Practice," Journal of Palestine Studies 48, no. 4 (2019): 7-16. P

11. See, among others, Maryam Abu Khaled, Facebook, June 8, 2020,

https://www.facebook.com/maryam.abukhaled.3/posts/1529644053876882 <

https://www.facebook.com/maryam.abukhaled.3/posts/1529644053876882> and Lama El

Amine, Facebook, June 2, 2020,

https://www.facebook.com/lama.elamine/posts/10158405087249324<

https://www.facebook.com/lama.elamine/posts/10158405087249324>-two examples drawn

from the contexts with which the author is most familiar. $P$

12. Hear remarks by Taylor Moore and Sophia Azeb, "Global Uprising: Racism, Racialization, AntiBlackness," Hagop Kevorkian Center for Near Eastern Studies, September 15, 2020, YouTube video, https://www.youtube.com/watch?v=kU0YD8j3av8 < https://www.youtube.com/watch? $\mathrm{v}=\mathrm{kU} 0 \mathrm{YD} 8 \mathrm{j} 3 \mathrm{av} 8>$. ?

13. See also Jasbir Puar, Terrorist Assemblages: Homonationalism in Queer Times (Durham: Duke University Press, 2007); Rayya El Zein, "From Hip Hop Revolutionaries to Terrorist Thugs: Blackwashing between the Arab Spring and the War on Terror," Lateral 5, no. 1 (2016), https://csalateral.org/issue/5-1/hip-hop-blackwashing-el-zein < https://csalateral.org/issue/51/hip-hop-blackwashing-el-zein/>. ?

14. On the return of ROTC to CUNY, see Hannah K. Gold, "ROTC Brings the Military Home to CUNY," Truthout, November 29, 2014, https://truthout.org/articles/rotc-brings-the-military-home-tocuny < https://truthout.org/articles/rotc-brings-the-military-home-to-cuny/>. P

15. The claim that non-Black Muslims harbor a particularly vile anti-Blackness is a trope of Orientalist literature of the likes of Bernard Lewis, among others. This idea has been reanimated in recent years in the work of Afropessimist thinker Frank Wilderson. Interestingly, this claim of his, manifest in experiences with a Palestinian acquaintance, has consistently been brought up in recent critiques of his Afropessimism (2020). See for example, Vinson Cunningham, "The Argument of 'Afropessimism,', The New Yorker, July 13, 2020, https://www.newyorker.com/magazine/2020/07/20/the-argument-of-afropessimism < https://www.newyorker.com/magazine/2020/07/20/the-argument-of-afropessimism> 
16. Jemima Pierre, The Predicament of Blackness: Postcolonial Ghana and the Politics of Race (Chicago: University of Chicago Press, 2012), 4.

17. See among others, Eve Troutt Powell, A Different Shade of Colonialism: Egypt, Great Britain, and the Mastery of the Sudan (Berkeley, CA: University of California Press, 2003); Chouki El Hamel, Black Morocco: A History of Slavery, Race, and Islam (Cambridge, UK: Cambridge University Press, 2014); Ehud Toledano, Slavery and Abolition in the Ottoman Middle East (Seattle: University of Washington Press, 1997); Matthew S. Hopper, Slaves of One Master: Globalization and Slavery in the Age of Empire (New Haven, CT: Yale University Press, 2015); Sussan Babaie, Slaves of the Shah: New Elites of Safavid Iran (London: I.B. Tauris, 2017).

18. See also Sherene Seikaly, "The Matter of Time," The American Historical Review 124, no. 5 (2019): 1681-1688; Sarah Gualtieri, Arab Routes: Pathways to Syrian California (Stanford, CA: Stanford University Press, 2019).

19. Cynthia Becker, Amazigh Arts in Morocco: Women Shaping Berber Identity (Austin: University of Texas Press, 2006) see also Blackness in Morcoo: Gnawa Identity through Music and Visual Culture (Minneapolis: University of Minnesota Press, 2020); Richard C. Jankowsky, Stambeli: Music, Trance, and Alterity in Tunisia (Chicago: University of Chicago Press, 2010); Ella Shohat, Israeli Cinema: East/West and the Politics of Representation (Austin: University of Texas Press, 1989); Ammiel Alcalay, After Jews and Arabs: Remaking Levantine Culture (Minneapolis: University of Minnesota Press, 1993); Ida Meftahi, Gender and Dance in Modern Iran: Biopolitics on Stage (New York: Routledge, 2016); Pedram Partovi, Popular Iranian Cinema Before the Revolution: Family and the Nation in Filmfārsī (New York: Routledge, 2017). \$?

20. Afshin Marashi, Nationalizing Iran: Culture, Power, and the State 1870-1940 (Seattle: University of Washington Press, 2008); Reza Zia-Ebrahimi, The Emergence of Iranian Nationalism: Race and the Politics of Dislocation (New York: Columbia University Press, 2016).

21. Farha Ghannam, Live and Die Like a Man: Gender Dynamics in Urban Egypt (Stanford, CA: Stanford University Press, 2013); Lara Deeb and Jessica Winegar, "Anthropologies of ArabMajority Societies," Annual Review of Anthropology 41, no. 1: 537-558; Ghassan Hage, White Nation: Fantasies of White Supremacy in a Multicultural Society (New York: Routledge, 2000).

22. Fatima El-Tayeb, European Others: Queering Ethnicity in Postnational Europe (Minneapolis: Minnesota University Press, 2011); Neda Maghbouleh, The Limits of Whiteness: Iranian Americans and the Everyday Politics of Race (Stanford, CA: Stanford University Press, 2017); Smadar Lavie, Wrapped in the Flag of Israel: Mizrahi Single Mothers and Bureaucratic Torture (London: Berghahn Books, 2014); Ronit Lentin, Traces of Racial Exception: Racializing Israeli Settler Colonialism (New York: Bloomsbury, 2018); Yehouda Shenhav, The Arab Jews: A Postcolonial Reading of Nationalism, Religion, and Ethnicity (Stanford, CA: Stanford University Press, 2006).

23. Fred Moten, In the Break: The Aesthetics of the Black Radical Tradition (Minneapolis: University of Minnesota Press, 2003); Marc D. Perry, "Global Black Self-Fashionings: Hip Hop as Diasporic Space," Identities 15, no. 6 (2008): 635-664; Daphne Brooks, Bodies in Dissent: Spectacular Performances of Race and Freedom 1850-1910 (Durham, NC: Duke University Press, 2006); Nina Sun Eidsheim, The Race of Sound: Listening, Timbre, and Vocality in African American Music (Berkeley, CA: University of California Press, 2018).

24. Stephen Johnson, Burnt Cork: Traditions and Legacies of Blackface Minstrelsy (Boston: University of Massachusetts Press, 2012); Virginia Mason Vaughan, Performing Blackness on English Stages, 1500-1800 (Cambridge, UK: Cambridge University Press, 2009); Nicholas Sammond, Birth of an Industry: Blackface Minstrelsy and the Rise of American Animation (Durham, NC: Duke University Press, 2015); Scott McCloud, Understanding Comics: The Invisible Art (Northhampton, MA: Kitchen Sink Press, 1993).

25. Wendy Brown, Regulating Aversion: Tolerance in the Age of Identity and Empire (Princeton, NJ: Princeton University Press, 2006); Slavoj Žižek, "Multiculturalism, or, the Cultural Logic of Multinational Capitalism," New Left Review (1997): 28-51; Didier Fassin, "Policing Borders, Producing Boundaries: The Governmentality of Immigration in Dark Times," Annual Review of Anthropology 40 (2011): 213-226; Paul Amar, The Security Archipelago: Human-Security States, Sexuality Politics, and the End of Neoliberalism (Durham, NC: Duke University Press, 2013). 
26. Seikaly, "The Matter of Time," 1687. P

27. Henry Louis Gates Jr., ed., "Race," Writing, and Difference (Chicago: University of Chicago Press, 1992). P

28. Patricia Hill Collins, Black Feminist Thought: Knowledge, Consciousness, and the Politics of Empowerment, 2nd ed. (New York: Routledge, 1999). ?

29. Orlando Patterson, Slavery and Social Death: A Comparative Study, 2nd ed. (Cambridge, MA: Harvard University Press, 2018). P

30. Frank Wilderson, Afropessimism (New York: Liveright, 2020).

\section{Author Information}

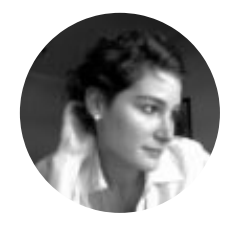

\section{Rayya El Zein}

Rayya El Zein is a cultural ethnographer and scholar of performance and media in the Middle East and its diasporas. Her multi-sited research focuses on the embodied aesthetics of live performances and activist practices, while exploring the cultural politics of contemporary media debates. Her interdisciplinary work rethinks representations of Arab and Muslim youth and proposes different models of subjectivity and agency attuned to lived experiences in the contemporary Middle East.

View all of Rayya El Zein's articles.

\section{Article details}

Rayya El Zein, "Introduction: Cultural Constructions of Race and Racism in the Middle East and North Africa / Southwest Asia and North Africa," Lateral 10.1 (2021).

https://doi.org/10.25158/L10.1.11

This content is licensed under a Creative Commons Attribution-NonCommercial 4.0 International License. Copyright is retained by authors.

Lateral is the peer-reviewed, open access journal of the Cultural Studies Association.

ISSN 2469-4053 